\title{
シールド装着状態のシリンジ製剂を用いた エネルギースペクトル収集法の検討
}

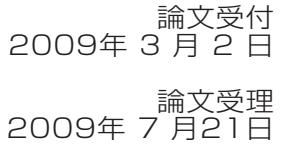

Code No. 922
宇戸朋之

市立池田病院医療技術部放射線科

\section{はじめに}

平成19年 3 月に厚生労働省が医療法に医療機器安 全管理責任者の配置を明文化している1 放射線技師の間ではquality control (QC) に関する知 識が広められていたが，これを機にさらにその気運 が高まった感がある，QCのための基本性能測定や点 検基準などを明記した規格等 ${ }^{2 \sim 6)}$ が公表されており参 考となるが，著者はそれらを参考にして当院で実施 しているユーザー点検の内容についてすでに報告し ている7)。そのなかで, ${ }^{99 \mathrm{~m}} \mathrm{Tc}$ c製剤についてはシリンジ シールドを装着した状態でのエネルギースペクトル収 集の妥当性を示した，今回は，主にシリンジ製剤とし て購入する, ${ }^{201} \mathrm{Tl},{ }^{67} \mathrm{Ga},{ }^{123} \mathrm{I}$ の 3 核種について検討
を行ったので報告する。

\section{1. 目 的}

主にシリンジ製剤として購入する, ${ }^{201} \mathrm{Tl},{ }^{67} \mathrm{Ga},{ }^{123} \mathrm{I}$ の 3 核種についてシリンジシールド装着状態の高い 放射能を持つ投与前製剂を用いてエネルギースペク トル収集を行う方法の妥当性を, 基準となる光電ピー ク値と比較することで検証した。

\section{2. 方 法}

\section{2-1 使用機器}

ガンマカメラは, RC2500IV (日立メディコ製)を使 用した，エネルギースペクトル収集に用いるコリメー

\section{Examination of Energy Spectrum Acquisition Method Using Shielded Radiopharmaceutical Syringes}

\section{Tomoyuki Uto}

Department of Clinical Radiation Technology, Ikeda Municipal Hospital

Received March 2, 2009; Revision accepted July 21, 2009; Code No. 922

\section{Summary}

I previously reported on a spectrum sampling method with shielded syringes before use, although the report included only data obtained using technetium-99m. In this study, we sampled the energy spectrum in a similar manner using thallium-201, iodine-123, and gallium-67. In spectrum sampling, a radioisotopic source in a cylindrical shield is located midway between two opposed gamma-camera detectors equipped with collimators. An unshielded syringe before use emits excessive radiation and makes count rates too high to obtain accurate photopeak values. With a shielded syringe, we can sample the spectrum of radiation leaked from the needle side of the syringe and the unshielded part of its plunger side. Consequently, the detectors are exposed to lower-dose gamma rays and probably offer count rates appropriate to measure accurate photopeak values. The study results show the general validity of spectrum sampling and photopeak acquisition in our method. However, a syringe should be located accurately perpendicular to each detector; otherwise, gamma rays did not reach the detectors in some cases, resulting in measurement failures. In addition, when low-energy collimators are used for sampling from ${ }^{123}$ I sources, photopeak values depend on penetration. More accurate measurements require the use of high-energy collimators.

Key words: energy spectrum sampling, shielded syringes, thallium-201, iodine-123, gallium-67 

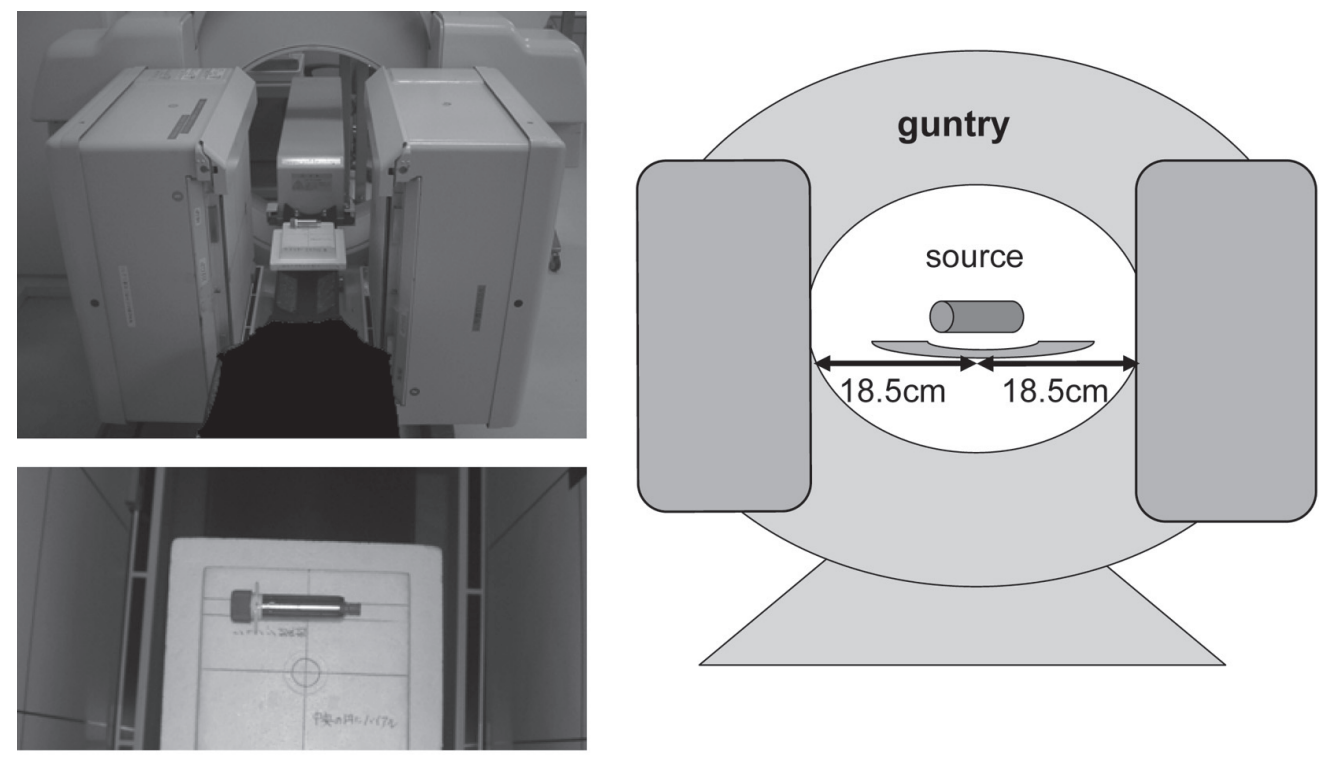

Fig. 1 Device overview and geometry for spectrum sampling.

タは, ${ }^{201} \mathrm{~T} 1$ は低エネルギー沉用型コリメータ(以下, LEGP), ${ }^{67} \mathrm{Ga}$ は高エネルギー汎用型コリメータ(以 下，HEGP)， ${ }^{123}$ Iでは，当装置に中エネルギー用コリ メータが用意されておらず，ガンマ線159keVまでを 低エネルギー用コリメータで対応するコンセプトであ り，それ以上のエネルギーに対して高エネルギー用コ リメータで対応するようになっているためLEGPを通 常使用している。しかし, 今回 ${ }^{123} \mathrm{I}$ の高エネルギー隔 壁通過の影響を比較するためにHEGPによる実験も追 加した。

線源放射能の測定にはALOKA製キュリーメータ IGC-7を用いた。

\section{2-2 エネルギースペクトルの収集について}

本論文で検討対象となるエネルギースペクトルの 収集方法を説明する。収集は装置に用意されている エネルギースペクトル収集ソフトを用いる。これは 2 検出器同時にマルチチャンネルでヒストグラムを収集 し, 一方の検出器でヒストグラムのピークカウントが 1000カウントに達するまで収集が続けられる。得られ たマルチチャンネルのヒストグラムは装置ディスプレ イに表示, 収集を終えると光電ピーク值が自動算出 され画面に表示される。次に収集時のジオメトリを説 明する，検出器にコリメータを装着し患者寝台をはさ むように左右に対向させ，その中央位置にシリンジ線 源をシールド装着のまま長手方向が検出器面に垂直 となるように配置する(Fig. 1)。このときシリンジは検 査ベッドの上に発泡スチロール製の台に乗せ，平ら なシリンジシールドの鉛ガラス部分を下にして安定さ
せる.シリンジ線源にはニードル装着側(以下，ニー ドル側)とプランジャ装着側 (以下, プランジャ側)の 両側にシールドによる遮蔽がなされていない部分が あり, ここから漏れ出すガンマ線を利用してエネル ギースペクトルの収集を行う。上記 3 核種では検査 のために購入したものを用いて検査使用前にエネル ギースペクトルの収集を行うが，検定日時で $111 \mathrm{MBq}$ の放射能を持つ場合，使用前線源はより多い放射能 を持つことになり，装置取扱説明書記載の推奨放射 能が37〜111MBq とあるが，エネルギースペクトル収 集時点ではその上限より多い放射能となる。しかしシ リンジシールド装着状態ではニードル側とプランジャ 側以外の放射線は遮蔽されており，検出される放射 線のカウントレートは目減りしエネルギースペクトル 収集に適当なカウントレートになると期待される。

\section{2-2-1 実験 1}

基準となる光電ピーク值を得るためシールドに収め ていない線源を用いるが，その放射能を決定するた め, バイアル内に封入した製剤の放射能を変化させ てエネルギースペクトルを収集し光電ピーク值を得 た。また，あわせてシリンジシールド装着状態で得ら れるカウントがバイアル線源でどの程度の放射能に 相当するかを調べるため, イメージングし画像カウン トを測定した。装置の配置はFig. 1のシリンジ線源の ところにシールドに収めていないバイアルを配置した. イメージングについては後述する実験 4 に準じた。

\section{2-2-2 実験 2}

シリンジシールドを装着した線源を用いてFig. 1の 線源配置でエネルギースペクトルを収集し光電ピー 
Table 1 Relationship between source radioactivity (MBq), image counts, and difference for reference of photopeak values (keV)

\begin{tabular}{|c|c|c|c|c|c|c|c|c|c|c|}
\hline$(\mathrm{MBq})$ & (counts) & $(*)$ & $(\mathrm{MBq})$ & (counts) & (*) & (counts) & $(*)$ & $(\mathrm{MBq})$ & \multirow{2}{*}{ (counts) } & $(*)$ \\
\hline 318 & 622383 & -9 & 643 & 495449 & -4 & 269148 & -5 & 699 & & -5 \\
\hline 142 & 438119 & -5 & 463 & 448310 & -2 & 215499 & -4 & 463 & $\begin{array}{l}868844 \\
778019\end{array}$ & -3 \\
\hline 120 & 388666 & -5 & 292 & 333865 & -2 & 145777 & -2 & 361 & 698051 & -3 \\
\hline 96.0 & 331824 & -2 & 202 & 247074 & -1 & 102801 & -2 & 253 & 557605 & -2 \\
\hline 75.9 & 270537 & -2 & 185 & 221880 & -1 & 93885 & -1 & 181 & 436024 & -2 \\
\hline 38.0 & 145466 & 0 & 127 & 164487 & 0 & 67075 & 0 & 151 & 360967 & -2 \\
\hline 14.5 & 58964 & 0 & 102 & 137501 & 0 & 54357 & 0 & 145 & 347815 & -1 \\
\hline 8.3 & 37189 & 0 & 75.4 & 102972 & 0 & 40283 & 0 & 129 & 323124 & -1 \\
\hline 318 & 598894 & -3 & 29.1 & 41580 & 0 & 16648 & 0 & 100 & 250761 & 0 \\
\hline 142 & 329167 & -1 & 10.8 & 16077 & 0 & 6876 & 0 & 52.1 & 138762 & 0 \\
\hline 123 & 273722 & -1 & 8.2 & 11882 & 0 & 5139 & 0 & 18.1 & 50884 & 0 \\
\hline 96.0 & 217699 & 0 & & & & & & 9.8 & 27827 & 0 \\
\hline 78.1 & 177758 & 0 & \multicolumn{8}{|c|}{$(*)$ difference for reference of photopeak value $(\mathrm{keV})$} \\
\hline 36.4 & 86199 & 0 & \multicolumn{2}{|c|}{ 123| by LEGP } & \multirow{2}{*}{\multicolumn{3}{|c|}{${ }^{67} \mathrm{Ga}(93 \mathrm{keV})$}} & & \multirow{2}{*}{\multicolumn{2}{|c|}{ V) ${ }^{201} \mathrm{TI}$}} \\
\hline 14.9 & 36172 & 0 & \multicolumn{2}{|c|}{ 123| by HEGP } & & & & \multirow{2}{*}{\multicolumn{2}{|c|}{${ }^{67} \mathrm{Ga}(185 \mathrm{keV})$}} & \\
\hline 8.3 & 22568 & 0 & & & & & & & & \\
\hline
\end{tabular}

ク值を算出し基準の值と比較し妥当性を確認した.

\section{2-2-3 実験 3}

Fig. 1の線源配置で, 線源配置角度を検出器に対し てシリンジの長手方向を直角(以下，0度)から 3 度ず つ変化させてエネルギースペクトルを収集し光電 ピーク值を算出，角度の影響を調べた。実験 2, 3 で エネルギースペクトルは 3 回収集し光電ピークは最 頻值を採用した。また実験に用いた製剂放射能はそ れぞれ検定日時で $111 \mathrm{MBq}$ の放射能を持ち，各測定は 納入日の午前中を想定しているので，納入日の午前 9 時にキュリーメータで測定した。各放射能は， ${ }^{201} \mathrm{Tl}$ $181 \mathrm{MBq},{ }^{67} \mathrm{Ga}$ が $185 \mathrm{MBq},{ }^{123} \mathrm{I}$ が $142 \mathrm{MBq}$ で，薬液量

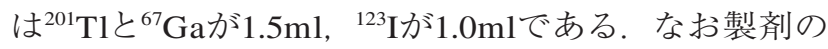
検定時の放射能はメーカーの基準範囲内で偏差があ ることをご了承願いたい.

\section{2-2-4 実験 4}

シリンジ構造を踏まえると両側から放出される放射 線の幾何学的状態が異なることが予想される。これ を確認するため, シリンジシールドを装着した線源を 用いてFig. 1に示す線源配置でシリンジシールドの ニードル側，プランジャ側それぞれから漏れ出すガン マ線をイメージングし, 画像からプロファイルカーブ を作成した。マトリクスは $128 \times 128$, ピクセルサイズ $4.16 \mathrm{~mm}$, 収集時間はカウントのオーバーフローを起 こさないように30秒とした。 この際メインウインドウ $20 \%$ と上下にサブウィンドウ $8 \%$ を設定し各ウィンド ウのイメージをそれぞれ取得した。 プロファイルカー ブは画像全面を対象に仮想スリットで得た。この画

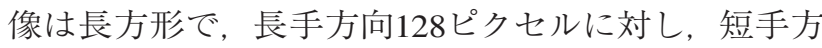

向は94ピクセルである，仮想スリットの設定は，画像 短手方向の 94 ピクセル分を平均しプロファイルの 1 点の值とし, 長手方向128ピクセルでも同様に行いプ ロファイルを得た。また画像の全カウントを測定し ニードル側とプランジャ側を比較した

\section{3. 結 果}

\section{3-1 実験 1}

放射能とイメージカウント, 光電ピーク值の関係を Table 1に示す。值は検出器 1 のデータのみである. 光電ピーク值は基準との差をもって示している. 光電 ピークは放射能が多いと基準の值を下回り，少ない 放射能へと変化していくにつれ安定する傾向をみせ ている。ささらに，推奨量より少ない放射能でも值は安 定している。エネルギースペクトル収集はマルチチャ ンネルのヒストグラム上ピークカウントが1000カウン 卜を得るまで続けられるので放射能が少ない場合は 時間がかかるが，カウントを一定とするため統計誤差 は線源放射能によらない。今回基準とした放射能は $10 \mathrm{MBq}$ 程度としたが，この設定に問題はないと考え る. 基準としたエネルギースペクトルをFig. 2に示 す。ここでは上段が検出器 1 , 下段が検出器 2 の結 果で, 検出器間で光電ピーク值が異なるが誤りでは なく日常的にこの程度の違いがみられる。

\section{3-2 実験 2}

0 度のシリンジ角度は正しい配置であるが，これで 得られる光電ピーク值と基準の光電ピーク值は, ${ }^{201} \mathrm{Tl},{ }^{67} \mathrm{Ga}$ では差がみられなかった. ${ }^{123} \mathrm{I} て ゙ は 159 \mathrm{keV}$, 


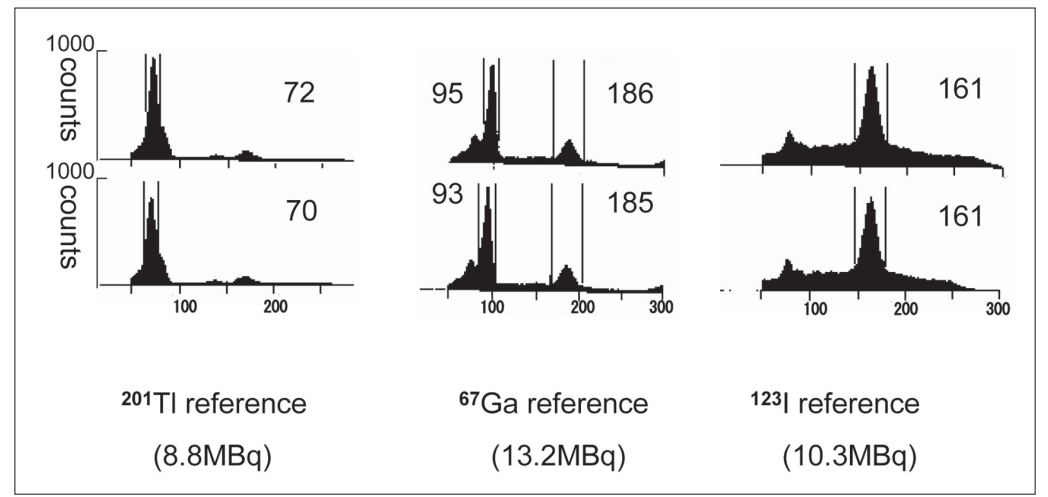

Fig. 2 Energy spectrograms and photopeak values obtained using an unshielded low radiation source.

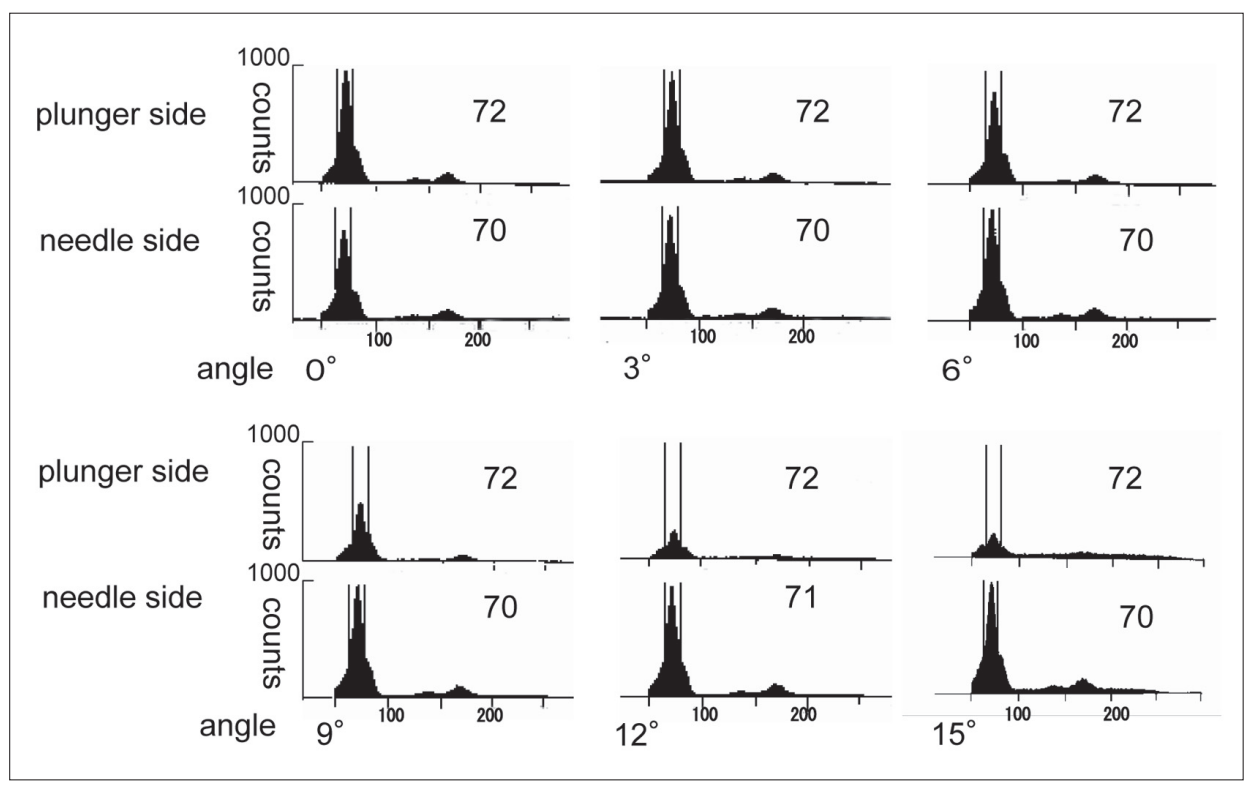

Fig. 3 Energy spectrograms and photopeak values for each angular position of a shielded syringe $\left({ }^{201} \mathrm{TI}\right)$.

$161 \mathrm{keV}$ とわずかな違いがみられた。

\section{3-3 実験 3}

シリンジ製剂の検出器に対する角度を変えて収集 した核種ごとのエネルギースペクトルをFig. 3〜 5に示 す。上段は検出器 1 でシリンジシールドのプランジャ 側の結果，下段は検出器 2 でニードル側の結果と なっている。 なお検出器とシリンジの向きが逆の組み 合わせでも実験を行っているが，傾向が同じなので 上記組み合わせのみを示した。 Fig. 2〜 5にみられる 光電ピークの右側に記述してある值が光電ピーク值 である。ここに示されるようにシリンジ製剤の角度に 伴いエネルギースペクトルの形状が変化した。また 光電ピーク值は変化を示す場合もあった。 なお，これ らエネルギースペクトルはディスプレイ表示ができる
のみで，装置から出力できず，ここに示す戝はディス プレイをデイジタルカメラで撮影した画像で，若干の ひずみがあることをご了承願いたい。

\section{3-4 実験 4}

ニードル側，プランジャ側それぞれから漏れ出す ガンマ線をイメージングした画像をFig. 6に，プロ ファイルカーブをFig. 7に示す. Fig. 7のサブウィンド ウのデータは高エネルギー側のみを示した。 ${ }^{67} \mathrm{Ga}$ につ いては93keVの画像と185keVの画像はほぼ同じ傾向

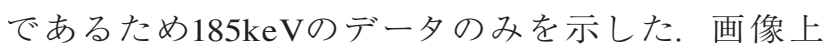
ニードル側とプランジャ側に大きな差はみられない

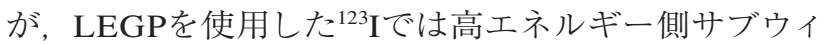
ンドウの画像でニードル側，プランジャ側が明確に異 なる画像であり, ニードル側でプランジャ側にはみら 


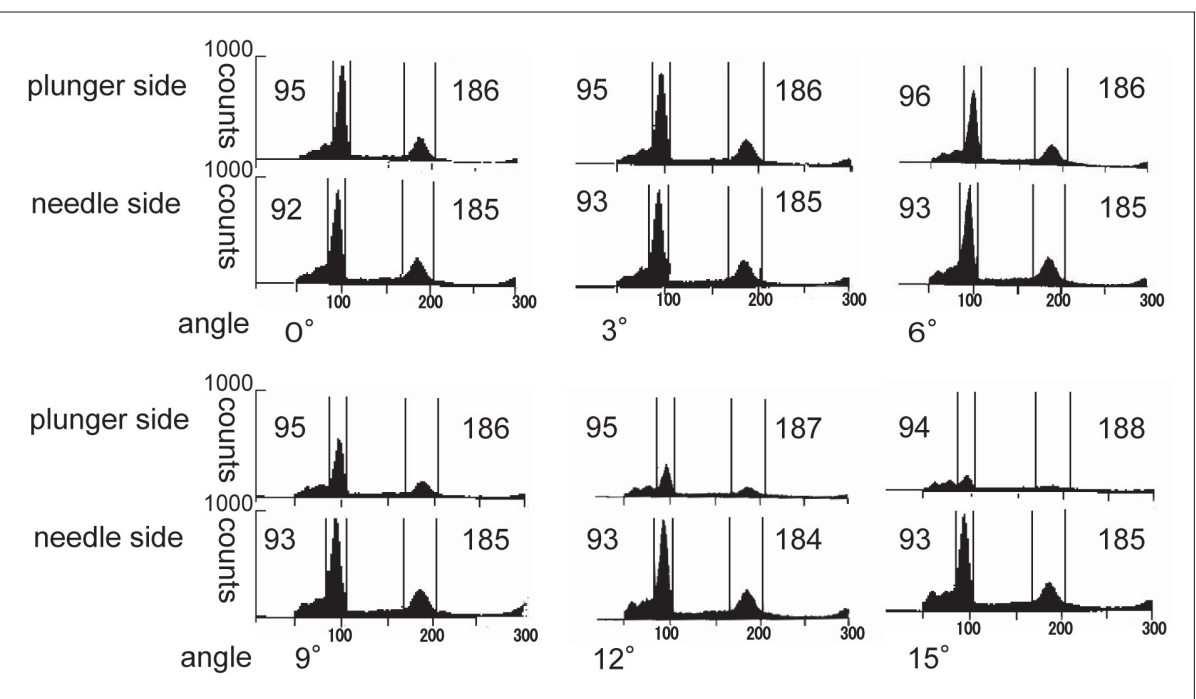

Fig. 4 Energy spectrograms and photopeak values for each angular position of a shielded syringe $\left({ }^{67} \mathrm{Ga}\right)$.

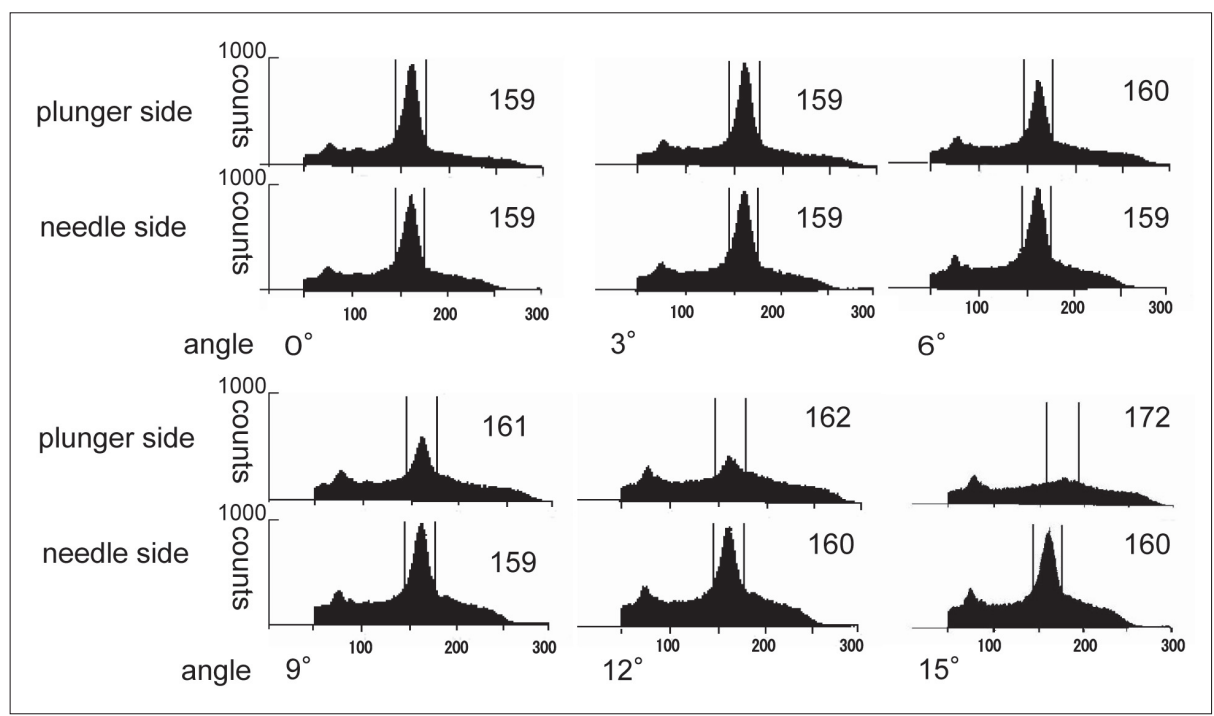

Fig. 5 Energy spectrograms and photopeak values for each angular position of a shielded syringe $\left({ }^{123} \mathrm{I}\right)$.

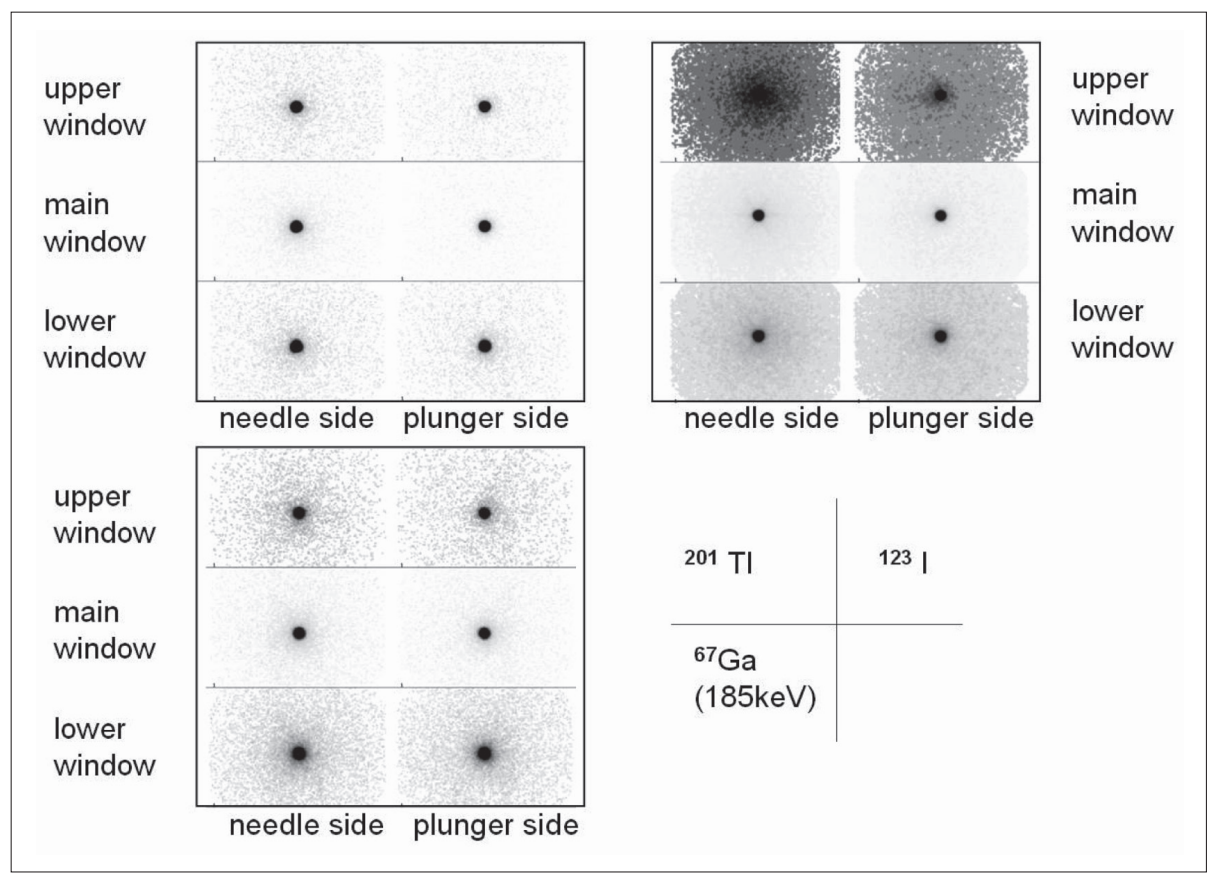

Fig. 6 Images of the needle and plunger sides of a shielded syringe. 


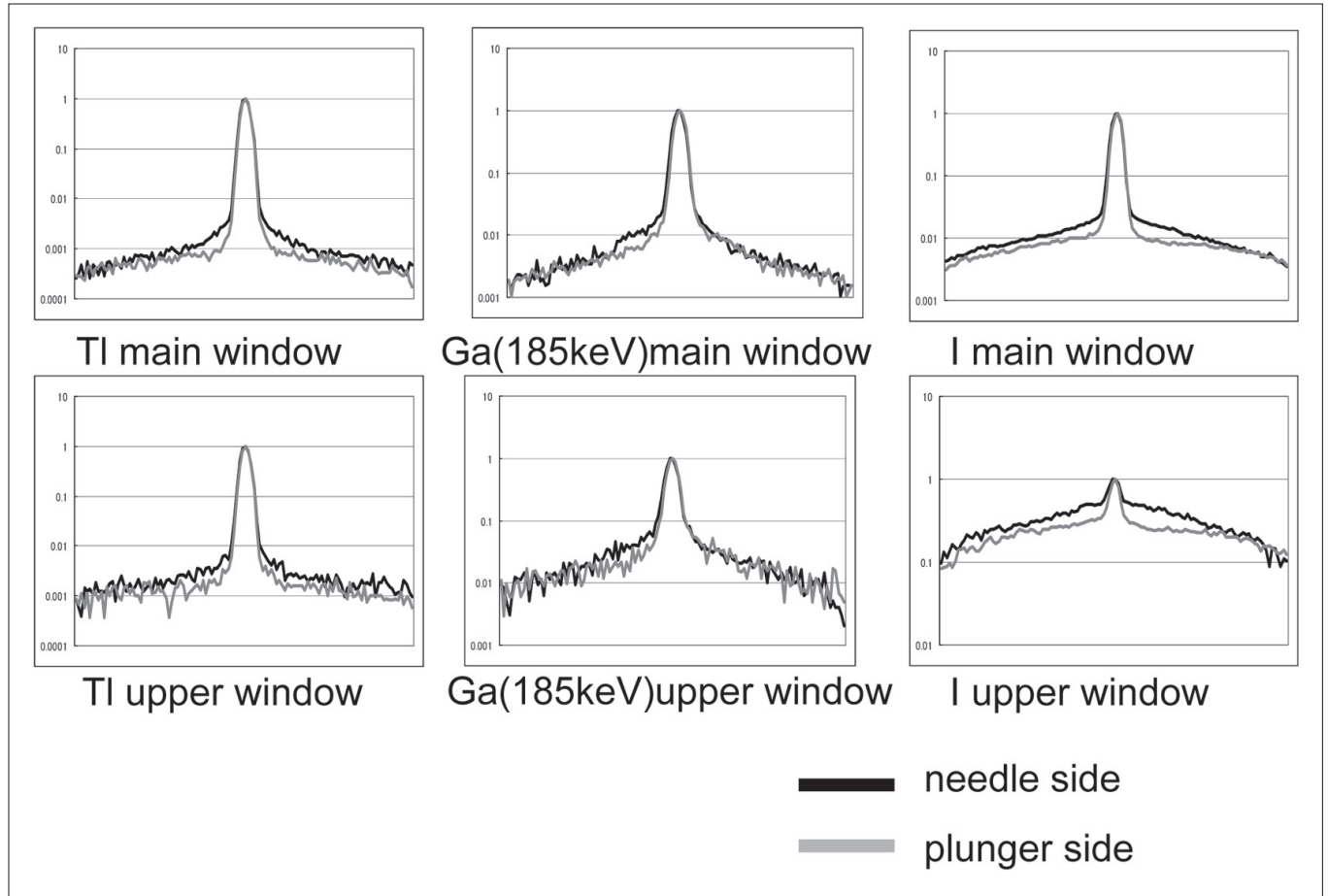

Fig. 7 Profile curve extracted from the images of a shielded syringe.

れないガンマ線の広がりがみられた。 LEGPを使用し た ${ }^{123} \mathrm{I}$ における高エネルギー側サブウィンドウでは, ニードル側でガンマ線の広がりが特に大きいが，そ れ以外でもわずかにニードル側のガンマ線が広がっ ている傾向が示された．測定したカウントをTable 2 に示す。LEGPを使用した ${ }^{123}$ Iではニードル側とプラン ジャ側のカウントに有意な違いはないが，その他はプ ランジャ側のカウントが高い. プランジャ側の值を $100 \%$ とすると ${ }^{67} \mathrm{Ga}$ では93keV，185 $\mathrm{keV}$ がそれぞれ 92\%，97\%となるのに対し ${ }^{201} \mathrm{~T} 1$ では $87 \%$ とその違いが 特に大きい.

\section{4. 考 察}

シリンジ製剤のシリンジシールドはFig. 8に示すよ うな構造をしており, ニードル側はプランジャ側より 開口面積が狭い。この構造は製剤の違いによらず同 一である。放射性医薬品はシールド内のガラス容器 に納まっており，ニードル側ではシールドの端から $6 \mathrm{~mm}$ まで薬剤が存在するが, プランジャ側は薬液量 に応じてシールドの端から離れた位置でとどまってい

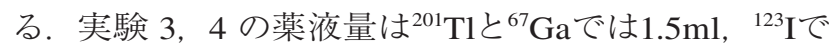
は1.0mlであり, プランジャ側のシールドの端からそ れぞれ $32 \mathrm{~mm}, 40 \mathrm{~mm}$ の位置となる. この幾何学的構 造のためニードル側から放出されるガンマ線は広い 角度に向けて放射されるが，プランジャ側から放出さ れるガンマ線は狭い角度に指向性を持つことになる。
Table 2 Image count and its ratio for a shielded syringe

\begin{tabular}{ccc}
\hline \hline & needle side & plunger side \\
\hline${ }^{201} \mathrm{TI}$ & $295326(87 \%)$ & $337986(100 \%)$ \\
\hline${ }^{67} \mathrm{Ga} 93 \mathrm{keV}$ & $150324(92 \%)$ & $163784(100 \%)$ \\
\hline $185 \mathrm{keV}$ & $68565(97 \%)$ & $70482(100 \%)$ \\
\hline${ }^{123}$ I (LEGP) & $309634(102 \%)$ & $305031(100 \%)$ \\
\hline${ }^{123}$ I (HEGP) & $208039(99 \%)$ & $210149(100 \%)$ \\
\hline
\end{tabular}

この状態をイメージングするとコリメータ孔に沿って 進行するガンマ線はイメージに現れるが, 斜めに進 行するガンマ線はコリメータ隔壁で遮蔽されてイメー ジに現れないので開口面積分のガンマ線がイメージ に現れ， ${ }^{201} \mathrm{Tl},{ }^{67} \mathrm{Ga}$ はプランジャ側のカウントがやや 高くなっている。両側から放出されるガンマ線の幾何 学的な違い故のカウントの違いを想定して実験 4 で 確認したが，コリメータが装着された検出器を通して 得られるイメージとしては大きな違いがない.

実験 1 で確認した放射能と光電ピーク值の関係よ り，正しい光電ピーク值を得るためには適した放射 能，すなわち適したカウントレートでガンマ線が検出 器に入射する必要があると思われる。使用前線源を シールド未装着で用いた場合の放射能では過㮃な力 ウントレートとなり正しい值が得られないが，シール 


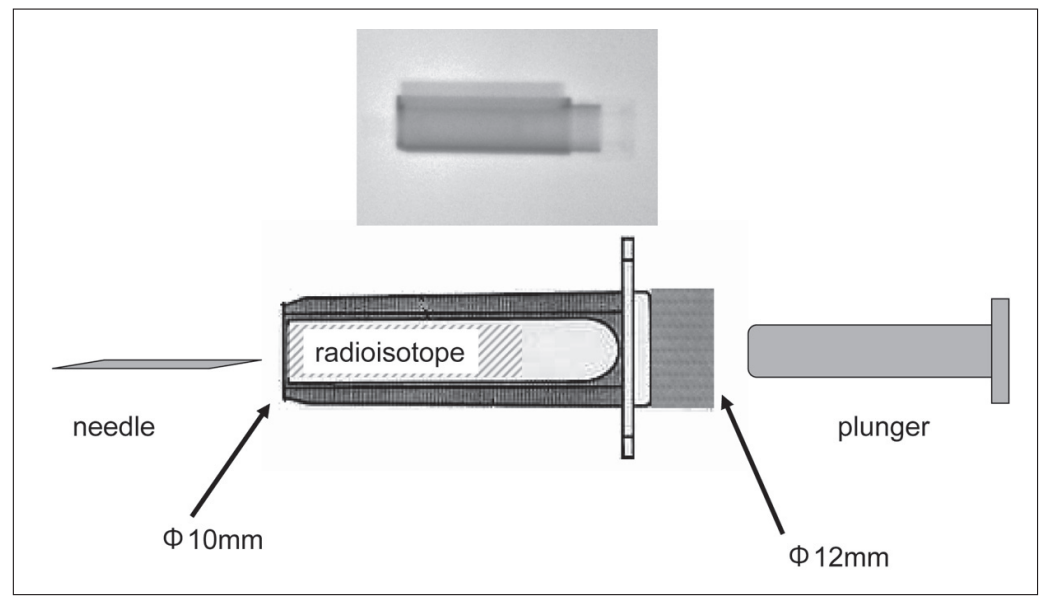

Fig. 8 Structure of syringe shield.
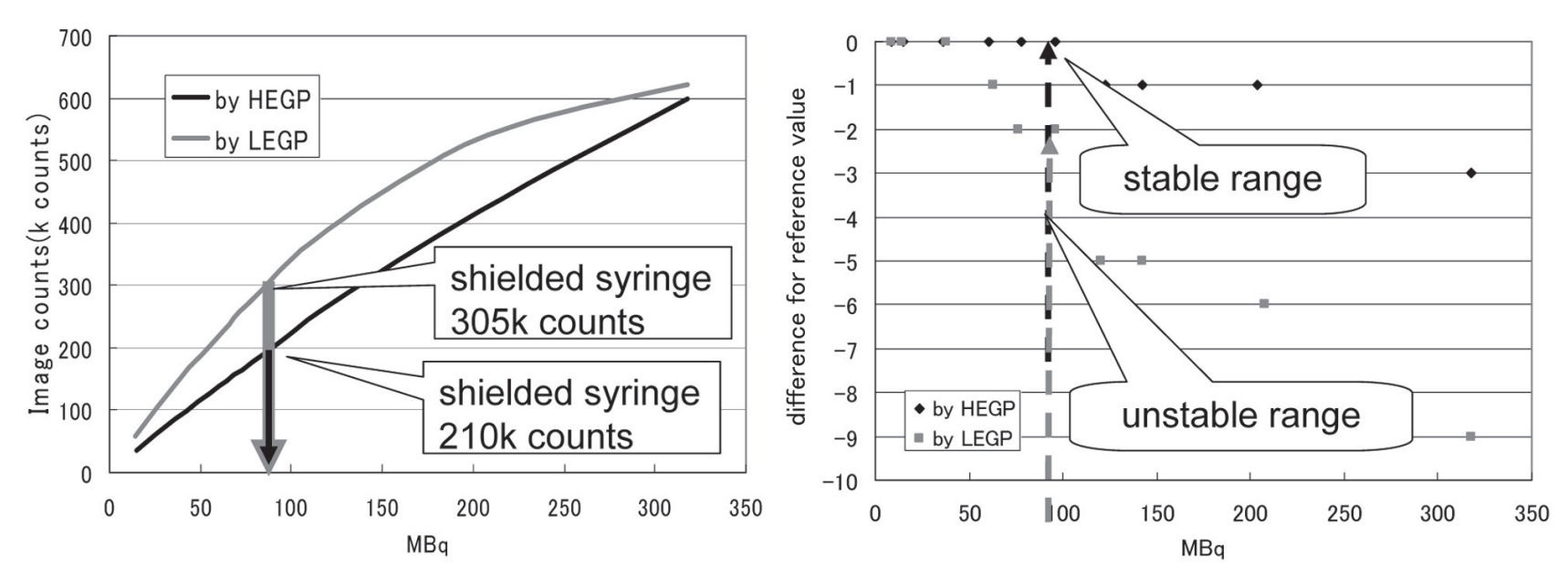

Fig. 9 Relationship between image counts of shielded syringe and photopeak value based source activity.

ド装着の状態では遮蔽によってカウントが目減りし光 電ピークを正しく得るのに適したカウントレートに なっていると予想される. Table 1の值をグラフ化し多 項式または直線近似から, Table 2のカウントを対応 させて, シリンジシールド装着時の見かけの放射能を 割り出すと, ${ }^{201} \mathrm{Tl}$ では $140 \mathrm{MBq},{ }^{67} \mathrm{Ga}$ では137MBq,

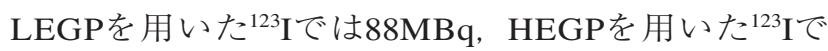
は93MBqとなり，実際の放射能より目減りしているこ とが分かる。 ${ }^{123} \mathrm{I}$ 例にすると, シリンジシールド装着 線源で得られたHEGPの場合のイメージカウント值の $210 \mathrm{k}$ countsは約 $90 \mathrm{MBq}$ に相当し，これを線源放射能 と光電ピーク值との関係に照らし合わせると, 光電 ピーク值が安定した領域に収まっている。この考察を Fig. 9に示す.

実験 3 の結果から ${ }^{201} \mathrm{Tl}$ と ${ }^{67} \mathrm{Ga}$ では基準の光電ピー ク值と等しい值が得られていることから，本方法にて エネルギースペクトルを収集し光電ピーク值を得るこ
とはこれらについては妥当であるといえる. 実験 4 で は角度が大きくなると光電ピーク值には大きな影響を 与えていない場合もあるがグラフには少しずつ変化 がみられる。エネルギースペクトル収集時のシリンジ 角度の許容範囲を示すならば影響が軽微な 6 度まで と思われる. シリンジ両側からのガンマ線放出には幾 何学的な違いがあり実験 4 のイメージカウントやエネ ルギースペクトルの光電ピークの高さから両側のカウ ントの違いがうかがえるが, 得られた光電ピーク值に は影響していないと思われる．しかしカウントの違い を少しでも是正するならばエネルギースペクトル収集 途中でシリンジを180度方向転換することで可能であ

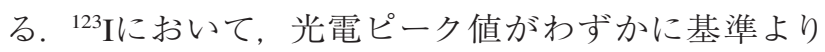

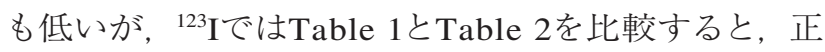
しい光電ピーク值を得るのに適したカウントレートよ りも高いカウントレートであるためと思われる。また シリンジ角度を大きくし光電ピークが示されないほど 


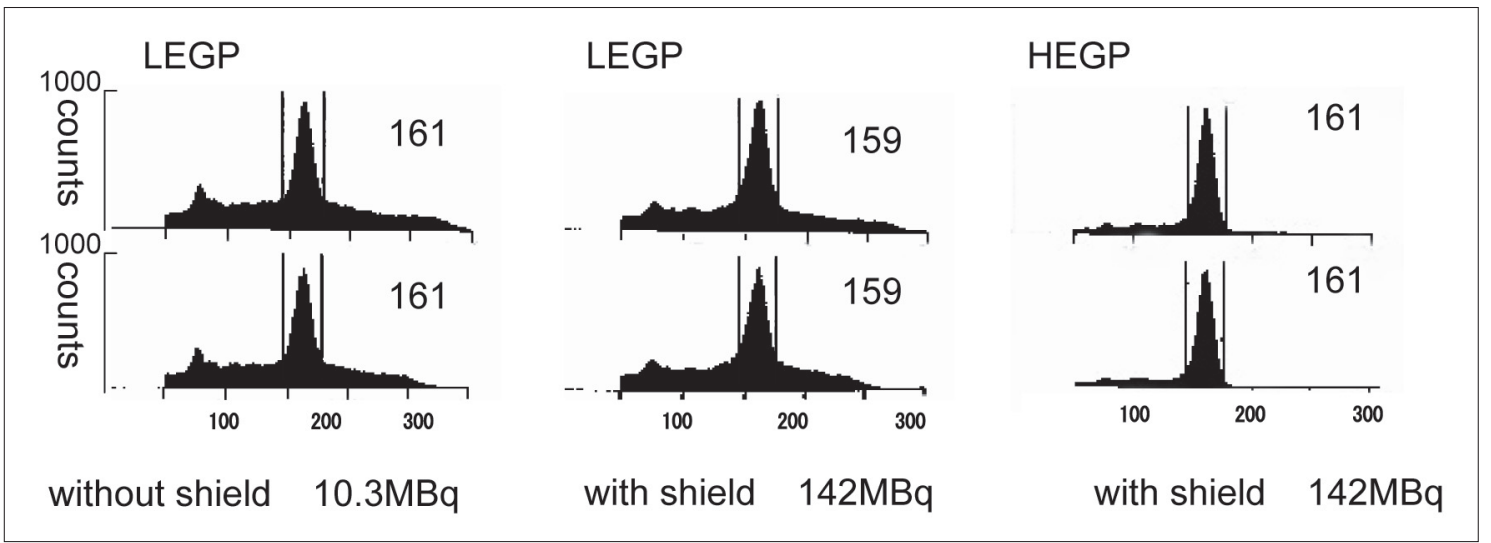

Fig. 10 Energy spectrograms and photopeak values for ${ }^{123}$ I-radioactivity for each collimator.

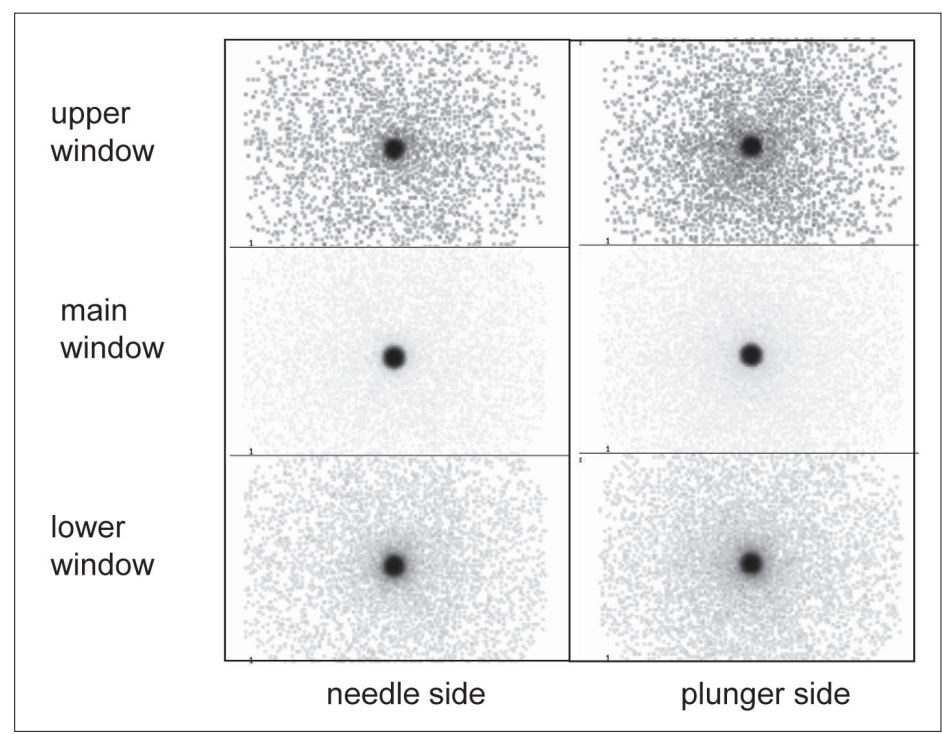

Fig. 11 Images of the needle and plunger sides of a shielded ${ }^{123}$-containing syringe with an HEGP collimator.

の角度配置としても，広いエネルギー範囲にわたって カウントが得られていること，またプランジャ側から 放出される指向性を持ったガンマ線に，これほどまで に角度がつくとコリメータ孔に沿うものは存在しない であろうが，それでもカウントが得られている要因と して考えられるのは，コリメータ隔壁をガンマ線が貫 くペネトレーションの影響と思われる。 ${ }^{123}$ Iで多くペネ トレーションを起こすのは529keVのエネルギーを持 つガンマ線であるが, 広いエネルギー範囲にわたつ てカウントを示すのは, このガンマ線が検出器にたど り着いてから生じる散乱線のためと思われる。このよ うに光電ピークより高いエネルギーにおいてもカウン トが得られていることが, サブウィンドウの高エネル ギー側のイメージに現れており，ニードル側でカウン 卜を示す部分が明らかに広がっているのはシリンジ シールドの構造上, ニードル側からのガンマ線が広
角に放出されており，コリメー夕孔に沿わないガンマ 線はかなり遮蔽されているもののペネトレーションを 起こして，いくらか広がりを保っているためと思われ る.このように ${ }^{201} \mathrm{Tl},{ }^{67} \mathrm{Ga}$ にはない特徵であるシリン ジ角度に対するエネルギースペクトルの変化の現れ 方や，エネルギースペクトル上での広いエネルギー 範囲にわたるカウントの底上げがみられることが， ペ ネトレーションの影響であると考え ${ }^{123} \mathrm{I}$ に対してHEGP を使用した実験も加えた。鉛隔壁の厚いHEGPは原理 的にペネトレーションが少ないと考えられ，これを用 いシリンジシールド装着の線源でエネルギースペクト ルを収集するとFig. 10のようにLEGPの場合とは大き く異なり広いエネルギー範囲にわたるカウントの底上 げがみられず, その光電ピーク值は基準值に等しく なった。またFig. 11に画像を示すがサブウィンドウの 高エネルギー側のイメージにみられた広がりはみられ 
なかった. HEGPでは本方法にて正しい光電ピーク值 が得られ，すなわち適したカウントレートに収まって いることがTable 1とTable 20比較によって示唆され る.あわせて前述の考察にも引用したFig. 9にも示さ れている。この違いは，コリメータ感度によるもの か, ペネトレーションによるカウントの底上げが除か れたことによるかは区別できない。このように本方法 で ${ }^{123} \mathrm{I} の$ 正しい光電ピーク值を得るために, HEGPを 使用することがより正確な方法と考えられる。このよ うにすると臨床で使用するコリメータとは異なる場合 が生じるが，あくまでカウントレートに対する措置で あり，臨床ではカウントレートが相対的に低いことも ありLEGPでの撮像で不都合は生じないと考えてい る.

\section{5. 結 論}

シリンジシールド装着状態のシリンジ製剤を用いて エネルギースペクトルを収集，光電ピーク值を得るこ とは，おおむね妥当であると思われる。また ${ }^{123} \mathrm{I} の$ 収 集をLEGPで行う場合，基準值と若干の差異がみられ たので，当装置において正確を期するにはHEGPの使 用が推奨される。

\section{おわりに}

シリンジ製剤は現在 2 社から供給されている。以 上いずれの検討も両社のシリンジについて行ってい るが，結果にメーカ間の違いが現れなかったため，示 した図表はそのうち 1 社のシリンジを使用した場合に 限定している.

\section{参考文献}

1) 医療法改正(平成19年 4 月 1 日施行予定)について。日放 技師会誌 2007；54(3)：289-291.

2) 大西英雄, 松本政典, 増田一孝. 核医学検査技術学. オーム社，東京，2002：173-189.

3) 橋本 宏, 深栖 一, 星野光雄, 他. JESRA X-51(ガン マカメラの性能測定法と表示法)の解説と関連規格との比 較。日放技学誌 $1986 ； 42(4) ： 548-564$

4）日本画像医療システム工業会. 日本画像医療システム工 業会団体規格 JESRA X51*A（ガンマカメラの性能測定法 と表示法)。東京, 1997 .
5) 日本画像医療システム工業会. 日本画像医療システム工 業会団体規格JESRA X67*A（ガンマカメラの性能の保守 点検基準)。東京, 1998.

6）利波紀久，金尾啓右，阿部欣二，他. 日本アイソトープ協 会医学・薬学部会，核医学イメージング・検査技術専門 委員会.ディジタルガンマカメラおよびSPECT装置の定 期点検指針. Radioisotopes 1998；47：427-434.

7) 宇戸朋之. 当院におけるガンマカメラユーザー点検. 日放 技師会誌 2008；55(6)：641-655.

\section{| | |}

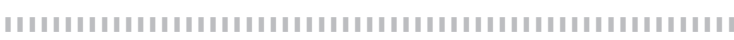

Fig. 1 エネルギースペクトル収集時の装置概観とジオメトリ

Fig. 2 シールドを装着していない低放射能線源を用いたエネルギースペクトル図と光電ピーク值

Fig. 3 シールド装着シリンジ製剤の角度ごとのエネルギースペクトル図と光電ピーク值 $\left.{ }^{201} \mathrm{Tl}\right)$

Fig. 4 シールド装着シリンジ製剤の角度ごとのエネルギースペクトル図と光電ピーク值 $\left({ }^{67} \mathrm{Ga}\right)$

Fig. 5 シールド装着シリンジ製剤の角度ごとのエネルギースペクトル図と光電ピーク值 $\left.{ }^{(123} \mathrm{I}\right)$

Fig. 6 シリンジシールド装着製剂のニードル側とプランジャ側のイメージング

Fig. 7 シリンジシールド装着製侴のイメージから求めたプロファイルカーブ

Fig. 8 シリンジシールドの構造

Fig. 9 線源放射能とイメージカウントとの関係，および線源放射能と光電ピーク(基準值との差)の関係

Fig. 10 123Iに扮ける異なる放射能, コリメータごとのエネルギースペクトルと光電ピーク值

Fig. 11 HEGPを使用した ${ }^{123} I$ Iリリンジシールド装着製剤のニードル側とプランジャ側のイメージング

Table 1 線源放射能とイメージカウント, および光電ピーク(基準值との差)の関係

Table 2 シリンジシールド装着製剤のイメージカウントと比 